\title{
Bosznia-Hercegovina gazdasági kilátásai és helyzetének történelmi háttere*
}

\author{
Kromják Laura
}

Az esszé Bosznia-Hercegovina gazdaságának társadalompolitikai kihívásait, valamint külkereskedelmi termék- és szolgáltatásforgalmát tárgyalja, érintve a magyar relációt. A vizsgálat leíró eszközökkel, szekunder adatokkal történik. A Horvátország és Szerbia közé ékelődött Bosznia-Hercegovina gazdasága elválaszthatatlan a múlt drámai eseményeitöl és a még megoldatlan társadalmi és politikai konfliktusoktól. Míg Jugoszlávián belül Bosznia-Hercegovina jelentös exportlehetöséggel rendelkező tagállam volt, a háború és az etnicizálódás a gazdaságot tönkretette. A daytoni rendszer államigazgatása drága, és lassan bontakoznak ki a tökeáramlás, a privatizáció és az európai felzárkózás alapjai. A devizamérleg egyensúlyozásában fontos szerepet kap a tőkeáramlás, az uniós elöcsatlakozási források és a nemzetközi támogatások. A folyó fizetési mérleg negativ egyenlegét csökkentő jelentős tétel a hazautalások összege, amelynek mértéke hatszor nagyobb, mint az FDI. A pénzátutalások a legnagyobb külső finanszírozási forrásává váltak, amely a függőséget növeli, a gazdaság sérülékenységét fokozza.

\section{Journal of Economic Literature (JEL) kódok: F14, F21, F24, F34}

Kulcsszavak: Bosznia-Hercegovina, kereskedelmi egyenleg, deviza-hazautalás, közvetlen tőkebefektetés, EU-integrációs előrehaladás

\section{Bevezetés}

A hat nyugat-balkáni ország (Szerbia, Bosznia-Hercegovina, Montenegró, Koszovó, Észak-Macedónia, Albánia) kilátásai - a közel 18 millió fős népességre támaszkodó fejlődő piaccal - kedvezőek. A GDP 2017-es 2,7 százalékos növekedése valamivel alacsonyabb, mint a 2016-os 2,9 százalék, de 2018-ra már 4 százalék, míg 2019ben 3,3 százalék a bővülés (WBG 2019). A Covid-19-járvány kitörése előtt a nyugat-balkáni országok többsége előrelépett, a szegénység csökkent és a háztartások jövedelme nőtt. A pandémia mély recesszióba sodorta a Nyugat-Balkán országait is, a globális kilátások továbbra is bizonytalanok, az Európai Unió gazdasága 8,4

* A jelen kiadványban megjelenő írások a szerzők nézeteit tartalmazzák, ami nem feltétlenül egyezik a Magyar Nemzeti Bank hivatalos álláspontjával.

Kromják Laura a Tomori Pál Főiskola adjunktusa.E-mail: Kromjak.Laura@tpfk.hu

A szerző köszönetet mond a két anonim lektornak hasznos javaslataikért.

A magyar nyelvű kézirat első változata 2020. december 8-án érkezett szerkesztőségünkbe.

DOI: http://doi.org/10.25201/HSZ.20.2.148169 
százalékkal, míg a nyugat-balkáni régió gazdasági aktivitása 4,8 százalékkal csökken 2020-ban. 2021-re a reál-GDP növekedésének becsült értéke az EU-27-ben 4,5 százalék, míg a Nyugat-Balkánon 3,5 százalék (WBG 2020a). Az Európai Bizottság 2021. téli gazdasági előrejelzése ${ }^{1}$ alapján 2022-ben az EU-27 gazdasága 3,9 százalékkal, míg a Nyugat-Balkáné 3,7 százalékkal fog nőni.

2019-ben is az EU-27 volt a Nyugat-Balkán fő partnere mind az exportban (68 százalék), mind az importban (61 százalék), a feldolgozott termékek 81 százaléka Nyugat-Balkánról származó uniós behozatal (Eurostat 2020). Magyarország 2019-2030as időszakra szóló Nemzeti Exportstratégiájában² az erőteljes keleti és déli nyitáson, a visegrádi és kárpát-medencei együttműködéseken túl kiemelt területként kezeli a nyugat-balkáni piacot. Támogatja a KKV-k piaci aktivitásának elősegítését, a magyar tőkekivitel élénkítését, a privatizációban való részvételt, és a rendelkezésére álló eszközökkel az uniós csatlakozás gyorsítását segíti.

A 3,3 millió lakosú volt jugoszláv utódállam, Bosznia-Hercegovina (BiH) külgazdasági kapcsolatrendszere négy stratégiai tengely mentén írható le. Bosznia-Hercegovina legjelentősebb külkereskedelmi partnere az export mintegy 72,3 százalékával az Európai Unió. A fő partnerország Ausztria, Németország, Hollandia, Olaszország, de a stabilizációt elősegítő nyugat-európai országok körébe tartozik Svájc is. A külkereskedelemben a jugoszláv utódállamok (kiemelten Szerbia, Szlovénia és Horvátország) részaránya szintén jelentős maradt, mintegy 1/3-nyi. Bosznia-Hercegovina együttmúködése az iszlám világgal - Törökországgal, az Egyesült Arab Emirátusokkal, Szaúd-Arábiával és Kuvaittal - sajátos külgazdasági jelenség a térségben.

Az esszé szekunder adatokra támaszkodó leíró kutatás, Bosznia-Hercegovina 20002020 közötti gazdasági helyzetét és kilátásait vizsgálja, arra a kérdésre keresve a választ, hogy képes-e fizetési mérlegét és áru- és szolgáltatásimportját finanszírozni. Az ország gazdasági helyzetének értéséhez indokolt a jugoszláv éra, az önállósodás és a háború utáni állapot vázlatos áttekintése, beleértve a még rendezetlen szerb és horvát területek, valamint az egymás mellett élő vallások és etnikumok viszonyát. Ebben a második fejezetben és az esszében visszatérő fogalom az etnicizálódás és a patronázsrendszer. Bosznia-Hercegovinában az etnikailag szerveződő politikai elit igyekszik ellenőrzése alatt tartani a privatizációs folyamatot, és a külföldi működőtőke-befektetéseknél a fejlesztési támogatásokat kisajátítani. A klientelista rendszer és a politikai etnicizálódás hátráltatja a gazdasági növekedést ${ }^{3}$.

\footnotetext{
${ }^{1}$ https://ec.europa.eu/info/business-economy-euro/economic-performance-and-forecasts/economicforecasts/winter-2021-economic-forecast-challenging-winter-light-end-tunnel_en

${ }^{2}$ https://2015-2019.kormany.hu/download/e/ca/91000/Nemzeti\%20Export\%20̄Strat\%C3\%A9gia\%2020192030.pdf\#!DocumentBrowse

${ }^{3}$ Papić, Z.: Ethicka privatizacija: neogranicene mogucosti prevare [Ethnic Privatization: unlimited possibilities for cheating]. Dani, Sarajevo, 1999. augusztus 6.
} 
A harmadik fejezet áttekinti Bosznia-Hercegovinának az Európai Unióba integrálódásának előrehaladását. A negyedik fejezet témája röviden az új nemzeti pénz, a konvertibilis márka és a currency board bevezetése. Az ötödik fejezet Magyarország és Bosznia-Hercegovina külkereskedelmi termék- és szolgáltatásforgalmát elemzi, érzékeltetve a magyar exportőrök és importőrök lehetőségeit. A hatodik fejezet rámutat, hogy a legsúlyosabb gazdasági probléma a nemzetközi fizetési mérleg pozíció. A kereskedelmi mérleg passzív, az importot sem a termelés, sem a fogyasztás érdekében csökkenteni nem lehet, így elengedhetetlen feltétel az export bővítése. Szükséges a tőkeimport növelése, mert a finanszírozó két tételre, a segélyekre és a külföldön munkát vállalók hazautalásaira perspektivikusan nem lehet hagyatkozni. A segélyek politikai döntésúek, a hazautalások generációs okokból fokozatosan visszaesnek. Az Európai Unióhoz való csatlakozás fontos szempont az Unió és Bosznia-Hercegovina általános érdekei között.

\section{Az önállósodás és a Dayton utáni Bosznia-Hercegovina: az elveszett évtized}

Bosznia-Hercegovina mintegy 600 év elteltével, 1992-ben a februári népszavazással vált ismét önállóvá. 1992. április 6-án, miután az Európai Gazdasági Közösség hivatalosan elismerte az ország függetlenségét a Jugoszláv Szövetségi Köztársaságtól, Magyarországgal is megtörtént az első nagyköveti szintű diplomáciai kapcsolatfelvétel. Jugoszlávia szétesését követően az 1995. november 21-én megszületett Daytoni Békeszerződés - amelyet formálisan december 14-én Párizsban írtak alá - lezárta a három és fél éves boszniai háborút. $A$ békeszerződés biztosította a konfliktus utáni politikai rendezést, az új alkotmányos státuszt, a regionális stabilizációt, a gazdasági rekonstrukció elkezdését.

A jugoszláv éra első két évtizedében Bosznia-Hercegovina volt az egyik legszegényebb tagköztársaság. A kis- és magánvállalkozásokkal jellemezhető mezőgazdaságával nem volt képes ellátni a belföldi keresletet, az élelmiszert többnyire importálták. Nagy átalakításra az 1950-es években került sor, amikor a jugoszláv szövetségi kormány a köztársaság szívében fekvő Bosznia-Hercegovinában előirányozta a nehézfém- és hadiipar stratégiai fejlesztését. Erőművek, acélművek, fémfeldolgozók létesültek, kiépült az elektroenergetikai szektor. Geostratégiai helyzete elősegítette, hogy a jugoszláv hadiipar fejlesztésének a központja legyen. Ugyanebben az időszakban a mezőgazdaság, az erdőgazdálkodás, az állattenyésztés is fellendült, és az élelmiszer, különösen a hús, a tejtermékek, a gyümölcsök, a zöldségek nettó exportőrévé lett (Bakota 2019; Čaušević 2013). Az export jelenleg a GDP 30 százaléka, amely az egyik legalacsonyabb Európában, de ha képes lenne annyit exportálni, mint a jugoszláv időkben, exportja megháromszorozódna (Goldstein et al. 2019). 1952-1965 között Jugoszlávia és benne Bosznia-Hercegovina aranykorát élte. 1950-1985 között a GDP növekedése Jugoszláviában (4,46 százalék) akkora volt, 
hogy azt csak Tajvan (6,64 százalék), Japán $(6,26$ százalék) és Kína $(5,10)$ haladta meg (Kovać 1995:282). Peštek et al. (2021) rámutat, hogy a háborút közvetlenül megelőző években Bosznia-Hercegovina a jugoszláv átlagnál több magas hozzáadott értékű terméket gyártott, kereskedelmi mérlege többletet mutatott. Az 1980-as évek második felében azonban Jugoszláviában megjelent a belső strukturális válság előszele. A gazdasági decentralizáció lassan haladt előre, és a hozzáférés a külföldi piacokhoz korlátozott volt. Gyengítette a konjunktúra lehetőségeit az ipar horizontális diverzifikációjának a hiánya. A szocialista „önigazgatás” modellje a nemzeti, a gazdasági, és az etnocentrizmusok erősödével felbomlott, majd a háború kitörésével megszűnt.

A háború után Bosznia-Hercegovina gazdasága romokban hevert. A GDP 1991-től 1992-re 80 százalékkal, 1991-ről 1995-re kétharmaddal esett vissza. A 4,3 millió fős népesség 1995-re az atrocitások és a menekültáradat eredményeként 1 millió fővel csökkent. „A boszniai háborúban a becslések szerint 100000 ember vesztette életét, akiknek 80 százaléka muzulmán bosnyák. Boszniában a civilek ellen elkövetett atrocitások a holokauszt óta a legsúlyosabb politikai indíttatású erőszak Európában" (Karamehic-Muratović - Kromják 2021:1). A több mint 8000 boszniai muzulmán férfi és fiú tömeges lemészárlását a kelet-boszniai Srebrenicában a Volt Jugoszláv Területeken Elkövetett Bűncselekmények Nemzetközi Törvényszéke (ICTY) 2001-ben háborús bűncselekménynek nyilvánította. A potenciális népírtás bűntettének nyomon követésével számos nemzet szerepel a megfigyelői listákon (Karamehic-Muratović - Kromják 2021).

Az 1990-es évek a jugoszláv térség és Bosznia-Hercegovina számára is elveszett évtized volt. A Jugoszláv Szövetségi Köztársaság szétesése, a piacok elvesztése, az évtizedek óta fennálló termelési láncok megszakadása, a fegyveres konfliktusok, a nemzetközi elszigeteltség, a szankciók, a rossz gazdaságvezetés és a korrupció hozzájárult a GDP drasztikus, 50 százalékos csökkenéséhez. Az ENSZ felmérése alapján 1999-ben a jugoszláv lakosság kétharmada szegénységben élt, azaz kevesebb mint 60 USD havi jövedelemmel rendelkezett. A háború mind a gazdaságot, mind az infrastruktúrát tönkretette: „A háború következtében a hidak 40 százaléka, míg az utak 35 százaléka vált használhatatlanná. A szarajevói repülőtér megsemmisült. Az ország 1000 kilométeres vasúthálózatában esett károk mértéke becslések szerint elérte az 1 milliárd amerikai dollárt" (MKIK 2020:18). Az elektromosáram-termelés eszközparkjának négyötöde odaveszett. A helyreállításhoz az országnak jelentős nemzetközi gazdasági, újjáépítési és humanitárius segélyre (többek között az EBRD 20 milliárd USD-os hitelkeretére) volt szüksége.

A Daytoni Békeszerződés „kísérlet” a Balkán szívének „egységes” országgá kovácsolására. 1995-ben alakult ki a mai megosztott, föderatív államszerkezet. Jelenleg a Bosznia-Hercegovinai Köztársaság két entitásból, illetve másodszintű kormányszervből áll: az ország 51 százalékát kitevő Bosznia-Hercegovinai Föderációból (Federacija Bosne i Hercegovine) - amely 8 bosnyák és horvát többségű kantonra és 
a fővárosra, Szarajevóra tagolódik - illetve a boszniai Szerb Köztársaságból (Republika Srpska, RS) Banja Luka központtal, amelyhez 63 helyi önkormányzat tartozik. A két entitás között megosztott Brčko város és környéke Brčko Kerület különleges jogállású, autonóm közigazgatási területe, amelynek kormányzatát közvetlenül a bosznia-hercegovinai állam - a helyi szervek mellett - az Európai Unióval közösen látja el. Mind a három közigazgatási entitás hivatalos nyelve a bosnyák, a szerb és a horvát. A 3,3 milliós népesség 50,7 százaléka muzulmán bosnyák, 30,8 százaléka ortodox szerb, 15 százaléka római katolikus horvát. Estrin - Uvalic (2014) kimutatta a közvetlen tőkebefektetések alacsonyabb volumene és a Balkán negatív megítélése közötti kapcsolatot, amely a potenciális befektetők régióról alkotott felfogására vezethető vissza.

Az 1995-ös daytoni béke biztosította a demokratikusan szervezendő állam alapjait, azonban az etnikai konfliktusokat nem szüntette meg. A területi entitások újrarajzolták Bosznia-Hercegovina térképét, és az államalkotó etnikai csoportok (muzulmán bosnyák, ortodox boszniai szerb, katolikus boszniai horvát) szerint konfigurálódtak. Az egységes gazdasági térség és közszféra kialakulását az állam keretében megbénítja az etnicizálódás, a patronázsrendszer és az etnikai érdekek mentén szerveződő kormányzati struktúra, amelynek fenntartása az ország GDP-jének közel a felét igényli. A politikai elitekhez kötődő vállalatvezetéssel a privatizációra kijelölt vállalkozások az érintett „etnikai oligarchiák” kezébe kerülhetnek (Vučetić 2002). Bosznia-Hercegovina ellenáll a modernizációnak, ragaszkodik az etnikai identitásokhoz, a politikai klientelizmushoz és a gazdaság azon formáihoz, amelyek a globalizációval és a strukturális átalakulással ellentétesek (Pugh 2005). Korábban Sells (1996:124) rámutatott a fejlett nyugati nemzetgazdaságok balkanizmusára, amely Bosznia-Hercegovina népéhez úgy közelít, mint „a józanság és a civilizáción kívüli törzsi gyűlölőkre".

A gazdasági újjáépítést és békekonszolidációt sürgető nemzetközi közösség figyelme a közvetlen társadalmi jólétet veszélyeztető gazdasági korrupcióra irányul, eltekint a klientelizmustól és a feketegazdaságtól, amely a gazdasági „túlélést” biztosítja. A támogató országok fejlesztésfinanszírozása a háborús vállalkozók és a helyi brókerek részvételével, a közös érdekek egybeesésével valósult meg (Pugh 2002; 2005).

A daytoni rendszer fenntarthatóságát az autonómiakövetelések elbizonytalanítják. A 83 százalékban ortodox boszniai szerbek által lakott boszniai Szerb Köztársaság 2015-ben népszavazási kezdeményezést indított a kiválásról. A 70,4 százalékban bosnyákok lakta Bosznia-Hercegovinai Föderációban a 23 százalékos arányt képviselő katolikus boszniai horvátok saját entitásalakításra törekszenek. A bosnyákok Bosznia-Hercegovina polgári állammá történő átszervezését hangsúlyozzák. Bosznia-Hercegovinában a gazdasági rekonstrukció egy tágabb béketeremtő folyamat része, középpontjában integrált stratégiával, amely figyelembe veszi a hosszú távú társadalmi és politikai tényezőket (Tzifakis - Tsardanidis 2006). A daytoni újjászer- 
vezést az európai uniós tagság követelményeihez és perspektívájához igazították. Bosznia-Hercegovina stabilitása az EU27-ek alapvető biztonsági érdeke, így támogatja euro-atlanti integrációját a NATO-ba, a WTO-ba és az Európai Unióba. Horvátország és Szerbia közé ékelődve Bosznia-Hercegovina nem kezelhető elkülönített térségként. „A három ország képletesen szólva is közlekedőedényként funkcionál, s a zágrábi, illetve belgrádi mozgások, történések azon mód lecsapódnak, megmutatkoznak Boszniában, és vice versa: minden Bosznia-Hercegovinán belüli turbulencia hatással van a horvát, illetve a szerb belpolitikára is" (Varga 2009:220). Bosznia-Hercegovina Magyarország 100 km-es rádiuszában van, Magyarország is támogatja a belső etnikai megosztottság és strukturális problémák orvoslásaként az európai integrációs folyamat felgyorsítását (Huszka 2015:117).

\section{A perspektívák: pozitív és negatív előjelek}

Az 1992 és 1995 közötti háborút követően a Hágával történő hatékony együttmüködésnek köszönhetően az ország az EU felé vezető útra lépett. 1997-ben kereskedelmi partnerségre léphetett az EU-val, és 1998-ban az EU technikai támogatását elősegítő közös munkacsoport alakult. 1999-ben az Európai Bizottság külpolitikai, stratégiai, gazdasági és jogi együttmúködést kötött az országgal. 2002. április 24-én az Európa Tanács tagja lett, majd más nyugat-balkáni országokkal együtt potenciális tagjelöltként nevezték meg az Európai Tanács 2003. júniusi thesszaloniki csúcstalálkozóján. Az EU-integrációs előrehaladás jeleként 2005-ben megkezdődtek a tárgyalások az EU-tagországok cégeivel az árucsere feltételeit szabályozó Stabilizációs és Társulási Megállapodás (SAA Interim) kereskedelmi jellegű részéről, amely végül 2008. július 1-én lépett életbe. 2007. május 1. óta a CEFTA-országok jelenléte is növekedett Bosznia-Hercegovina piacán. A 2008-ban elindult vízumliberalizáció eredménye a 2010. december 15-én hatályba lépett a bosznia-hercegovinai állampolgárok EU-s vízummentessége.

Mivel az EU az alkotmány módosításához kötötte a további uniós integrációs lépéseket $^{4}$ (ECHR 2009), Brüsszel és Szarajevó között hét év után, 2015. június 1-én zárult le a Stabilizációs és Együttmúködési Megállapodás (SAA) ${ }^{5}$ ratifikációs folyamata. Az SAA életbe lépése után a vámok, kvóták, illetékek fokozatosan minimumszintre csökkentek. Az SAA mérföldkőnek számít az ország európai uniós gazdasági integrációjában. 2016. szeptember 9-én Bosznia-Hercegovina kormánya elfogadta az SAA kiigazításáról szóló jegyzőkönyvet (Adaptation Protocol - AP), amely 2017. február 1-én lépett életbe. Rövid távon az SAA AP vámbevétel-veszteséget okozott (a mezőgazdasági és élelmiszerimport maximális vámbevétel-vesztesége a becslések szerint évi 26-35 millió euro között mozoghat), és további nyomást gyakorolhat egyes ágazatokra. Az SAA AP azonban Bosznia-Hercegovina EU-ból származó

\footnotetext{
${ }^{4}$ A kisebbségek diszkriminációjának megszüntetésére vonatkozóan

${ }^{5}$ Stabilisation and Association Agreement
} 
mezőgazdasági és élelmiszerimportjának mindössze 8 százalékát érinti, hisz a mezőgazdasági és élelmiszerimport többségét korábban már liberalizálták. Az új AP az ország mezőgazdasági és élelmiszeripari termékei számára a bor, a cukor és a hal uniós exportjára vonatkozó kvóták növelésével kedvezményes hozzáférést biztosít az EU piacához. Az uniós mezőgazdasági és élelmiszertermelők boszniai piacra jutását számos termék vámkontingenseinek (TRQ) csökkentésével segítették (WBG 2017). Az ipari termékek vámmentessége, valamint a mezőgazdasági termékekre vonatkozó kiegészítő rendelkezések az Európai Unió és Bosznia-Hercegovina közötti árukereskedelem liberalizálását segítik.

2010 óta Bosznia-Hercegovina igyekszik további lépéseket tenni az EU felé közeledésben. A szellemi tulajdonjogok EU-kompatibilis kialakítása mellett az európai uniós tenderlehetőségek nyújtotta fejlesztések miatt a 2004-es, kevésbé transzparens közbeszerzési rendszer harmonizációját is elvégezte. Végül, a volt Jugoszlávia országai közül (Koszovót leszámítva) utolsóként 2016. február 15-én hivatalosan is benyújtotta európai uniós csatlakozási kérelmét.

Az Európai Bizottság 2019 májusában az ország uniós tagsági kérelméről szóló véleményben (Avis), meghatározta azt a 14 fő prioritást, amelyet az országnak teljesítenie kell az EU-csatlakozási tárgyalások megkezdésének feltételeként, s amelyeket az EU Tanácsa átfogó ütemtervként 2019 decemberében jóváhagyott. Öt év patthelyzet után, 2020 júliusában Szarajevóban a parlamenti képviselők megállapodtak az EU - Boszniai Stabilizációs és Társulási Parlamenti Bizottság eljárási szabályzatáról, amellyel Bosznia teljesítette az Európai Bizottság egyik kiemelt elvárását.

\section{Bosznia-Hercegovinában a nemzeti pénz a konvertibilis márka}

Bosznia-Hercegovina Központi Bankját $\left(\mathrm{CBBH}^{6}\right) 1997$ végén alapították. 1998-ban kibocsátották az új nemzeti pénzt, a konvertibilis márkát (KM), amely egységesítette a három entitás pénzügyi szféráját. A német márkát minden fél elfogadta ${ }^{7}$, ezért a konvertibilis márka árfolyamát a német fizetőeszközhöz kötötték. Miután 2002ben a német márkát felváltotta az euro, a konvertibilis márkát ugyanazon a kötött árfolyamon váltották be az EU új fizetőeszközére, mint a német márkát (1 KM = 0,511292 EUR). Ezt követően a CBBH nem folytatott szuverén monetáris politikát, hanem valutatanácsi rendszert tartott fent. A currency board eredményeként az inflációt sikerült leszorítani és alacsonyan tartani, illetve visszanyerni a lakosság nemzeti fizetőeszköz iránti bizalmát, amit a konvertibilis márkában elhelyezett

${ }^{6}$ Central Bank of Bosnia-Herzegovina

${ }^{7}$ A nemzeti pénzek elértéktelenedése miatt de facto már korábban is ezt használták. 
betétek növekvő aránya jelez ${ }^{8}$. A konvertibilis márka euróhoz kötése megnövelte a külföldi befektetők bizalmát, és javította az ország makrogazdasági kilátásait (Ilgün és Coskun 2009). 2012. június 1-jén új sorozatot bocsájtottak ki a 10, 20, 50 és 100 KM bankjegyekből, amelyek a CBBH (2017) jelentése szerint európai színvonalú biztonsági elemeket tartalmaznak.

\section{Magyarország és Bosznia-Hercegovina külkereskedelmi termék- és szolgáltatásforgalma}

Bosznia-Hercegovina exportjának a GDP-hez viszonyított aránya 1994-ben 15 százalék, huszonöt évvel később ez az arány megemelkedett 40 százalékra. A változás mértéke erőteljesen függ fő kereskedelmi partnereinek részesedésétől - Németország (13 százalék), Olaszország (11,3 százalék), Horvátország (10,8 százalék) Szerbia, (10,6 százalék) - és a világgazdasági konjunktúrától. A Bosznia-Hercegovinai Statisztikai Hivatal szerint (2020. július) 2018-ban az ország globális kereskedelmi forgalmában az áruk exportja 12,1 százalékkal növekedett, és elérte a 9,8 milliárd eurót, míg az import összértéke a 6,084 milliárd eurót (+10,7 százalék). A kereskedelmi szolgáltatásokban az export 1,7 milliárd euro az 523 millió eurós importtal szemben. 2019-ben az export 5,875 milliárd euró, ami 3,4 százalékkal alacsonyabb, mint 2018-ban, az import 9,9 milliárd euro, ami 1,2 százalékkal magasabb. A kereskedelmi szolgáltatások exportja 1,9 milliárd euróra, az importja 633 millió euróra növekedett. Bosznia-Hercegovina kereskedelmi mérlege strukturálisan hiányos. A Lloyds Bank (2019) a Külföldi Befektetéseket Ösztönző Ügynökség, a FIPA (2020) adataira támaszkodó elemzése alapján 2019-ben a kereskedelmi hiány éves szinten 17 százalékkal nőtt. A külkereskedelem fejlődését továbbra is hátráltatja az alacsony termelékenységi szint, a finanszírozáshoz való korlátozott hozzáférés és az adminisztratív akadályok. A vámok a legtöbb termék esetében viszonylag alacsonyak, de különféle nem tarifális korlátok érvényben vannak. Dömpingellenes és kiegyenlítő vámokat időnként kivetnek a helyi ipar védelmére, ha az áru ára jóval a belföldi piaci ár alatt van, vagy ha azt államilag támogatják (Lloyds Bank 2019).

A Bosznia-Hercegovinával folytatott kétoldalú gazdasági kapcsolatainkban az áruforgalom dominál. A Statisztikai Hivatal szerint 2019-ben Bosznia-Hercegovina Magyarország negyvenedik kereskedelmi partnere volt, részaránya a teljes magyar külkereskedelemben 0,2 százalék. Magyarország a teljes boszniai külkereskedelemben 2,58 százalékos részarányával a kilencedik legfontosabb kereskedelmi partnere. Az elmúlt húsz évben kétoldalú külkereskedelmi kapcsolataink fejlődtek (KSH 2020). A 2001. évtől 2019 végére hazánk behozatalának külkereskedelmi értéke folyó áron

\footnotetext{
${ }^{8}$ A konvertibilis márka mellett a turisztikailag meghatározó városokban a fizetési gyakorlatban a kuna, az euro és - a bosznia-hercegovinai Szerb Köztársaság területén - a szerb dinár is jelen van, lásd: Milekic, Sven: Welcome to Mostar, a Town of Many Currencies. Balkanlnsights, 2017. június 16. https://balkaninsight. com/2017/06/16/welcome-to-mostar-a-town-of-many-currencies-06-15-2017/. Letöltés ideje: 2020. november 7 .
} 
5,96 millió euróról 142 millió euróra, a magyar kivitel 230 millió euróról 317 millió euróra nőtt, utóbbi 164,3 százalékos változás.

A szolgáltatások külkereskedelmi értéke 2008-tól 2019 végéig megduplázódott. 2008-ban az össznyugat-balkáni szolgáltatásexport 3,4 százaléka bonyolódik Bosznia-Hercegovinával, 2017-ben már a 6,4 százaléka. A 2018-as és 2019-es lassulás ellenére a 2008 és 2017 közötti duplázódás dinamikus fejlődésről tanúskodik, hasonlóan a már tagjelölt Albániához és Észak-Macedóniához.

A Magyar Kereskedelmi és Iparkamara exportőr-adatbázisa alapján a legfontosabb exportszolgáltatásunk Bosznia-Hercegovinába az alternatív és megújuló energia (szennyvíz- és hulladékkezelési technológiák), a vízgazdálkodás (klórozók, klór-dioxid-adagolók), az agrár-és élelmiszerfeldolgozó technológia (gabonatároló és silórendszerek), ICT (IP alapú komplex távközléshálózati megoldások, ügyfélhívó-rendszerek), a K+F tudásintenzív szolgáltatás- és technológiatranszfer (folyadékkromatográfia), a mérnöki szolgáltatás és kiállításszervezés, a gyógyászati technológia (nyugalmi és terheléses EKG-rendszerek). A bosznia-hercegovinai Külkereskedelmi Kamara adatai alapján Magyarország irányába a legnagyobb hányadot a nemzetközi szállítás képviseli.

A KSH és a bosznia-hercegovinai Statisztikai Hivatal adatai alapján gazdasági kapcsolatunk 2018-ig élénkült, majd egyre negatívabb a változás, a magyar aktívum jelentős. A magyar export a két évvel korábbiakhoz képest 21,6 százalékkal, az import 54,1 százalékkal növekedett. 2019-ben a magyar kivitel 12 százalékkal, míg a boszniai 15 százalékkal lassult, 2020-ban a pandémia a harmadik negyedévig mindkét oldalon több mint 80 százalékos visszaesést okozott (AS of BiH 2021).

Az 1990-es évek háborús pusztításait megelőzően, Jugoszlávia tagköztársaságaként prioritást élvezett a nehéz- és a hadiipar, arányuk a GDP-ben 51 százalék volt. Szemben ezzel 1999-ben az ipar és a bányászat súlya csupán 23 százalék (Pap 2004:52-53). Létrejöttek a nehézipari rozsdaövezetek, a hangsúlyt a magánkézben múködő mezőgazdaságra helyezték. A birtokok kis mérete azonban akadályozta a jelentősebb mezőgazdasági termelés elérését. A kisgazdaságok a túlélést és önellátást biztosították, termelésük alig járult hozzá a piachoz. Így Bosznia-Hercegovina élelmiszerimportja a kétezres évek elején 16-szor magasabb élelmiszerexportjának értékénél (Tzifakis - Tsardanidis 2006).

2017-ben az ipari termelés növekedési üteme 5 százalék, főbb iparágai az acélgyártás, a szénbányászat, a vasipar, az autóipar, a textilipar, a dohánygyártás, a bútorgyártás és a kőolaj-feldolgozás. Az ország gazdasága erősen függ színesfémexportjától, a befektetések jó része a termelő ágazatokat (34 százalék) és a banki szektort (22 százalék) érinti (MKIK 2020). A Trading Economics adatai alapján Bosznia-Hercegovina legfontosabb exporttermékei, egyben a jelentősebb magyar import termékei: 
vas, rozsdamentes acél, fa, faszéntermékek, bútorok, fényfeliratok, előregyártott épületek, gépek, kazánok, elektronikus- és mechanikai berendezések, cipőipari termékek. Az ország elsődleges importtermékei, amelyek egyben a jelentősebb magyar exporttermékek: élelmiszerek (gabona, állati zsírok, étolaj), elektromos gépek, személyautó és egyéb gépjármúvek, ásványi üzemanyagok, vegyszerek, műanyagszármazékok, kozmetikai és gyógyszeripari termékek.

A 2013-as magyar behozatali volumen tükrözi Bosznia-Hercegovina gazdasági helyzetét. A KSH adatai alapján a mindösszesen 96,7 millió eurós behozatal 90 százalékát közel 84 millió euro értékben a feldogozott termékek teszik ki. Bosznia-Hercegovinánál a 308,7 millió eurós behozatal 22 százaléka az élelmiszer, ital, dohány, és 42 százalék a feldolgozott termékek hányada. A 2017-es 156 millió euro magyar importból 137 millió euro a feldolgozott iparcikkek értéke (vegyi áru, szervetlen vegyi termékek, fémtermékek, nemfémes ásványból készült termékek, lábbelik, parafa- és fatermékek), így az arány lényegében nem változott. Bosznia-Hercegovina gazdaságának alapja a természeti erőforrásokra alapozott kitermelő- és feldolgozóipar. A magyar import kiemelt területei továbbra is az ásványi anyagok, színesfém, korund, vas, alumínium és acél, fémtartalmú ércek és fémhulladék, gépek és alkatrészek (pl. autóalkatrészek), fa és fatermékek (pl. faszén, bútor, papír). A 2020-as években a bosznia-hercegovinai import kiemelten fontos termékcsoportjai az infrastrukturális hálózatok (utak, alagutak, hidak, fütőművek, csatorna és vízvezeték) felújításához és fejlesztéséhez szükséges gépek, technológiák, és az élelmiszerellátás szempontjából a mezőgazdasági termékek, a mezőgazdasági kisgépek, a vegyszerek.

\section{A gazdasági felzárkózás és nemzetközi fizetési mérleg: az önfinanszí- rozás deficitje?}

A Világbank és a Bosznia-Hercegovinai Központi Bank adatai alapján a háborús pangás után a GDP üteme 2003-2008 között évi 5 százalékkal, dinamikusan emelkedett, egészen a 2008-2009-es gazdasági világválságig. A 2000-es évek első felében a gazdasági növekedés üteme a nemzetközi támogatások és humanitárius segélynyújtás csökkenése miatt stagnált. Az UNOCHA adatbázisa szerint ${ }^{9}$, míg 2000-ben 17,7 millió USD összegben érkezett támogatás - főleg az Amerikai Egyesült Államok és Németország kormányától multiszektorális, de kiemelten az egészségügyi rekonstrukciót segítve - addig 2002-ben már csak 9,5 millió USD, 2003-ban pedig 4,9 millió USD volt a humanitárius célú támogatás. A nemzetközi támogatások nem eredményeztek fenntartható gazdasági növekedést. A nemzetközi segélynyújtás csökkenése a gazdasági növekedés lassulásához vezetett. A donorországok teljes ellenőrzésük alatt tartották forrásaikat a belpolitikai hatalomgyakorlás érdekében (Tzifakis és Tsardanidis 2006). Az 1996-2001 közötti időszakban a nemzetközi segélyek

\footnotetext{
${ }^{9}$ https://fts.unocha.org/countries/28/flows/2019
} 
(5 milliárd USD) nagy részét alapvető infrastrukturális fejlesztésekre költötték. Komoly közvetlen tőkebefektetés (1,3 milliárd euro) megjelenésére 2007-ben került sor (Peštek et al. 2021).

A gazdaság stabilitásának fenntartásához a háború után az adósságállomány törlesztését átütemezték. A magas GDP-arányos külső államadósságot (35 százalék) 2007re sikerült fokozatosan levinni 20 százalék alá, a gazdasági világválság eszkalálódásával azonban 2014-re ismét 30 százalék fölé kúszott. Ezzel egyidejüleg a központi költségvetés egyenlege is hiányt mutatott, és csak 2015-ben fordult át többletbe, a válságot megelőző ígéretes szintet pedig először csak 2017-ben közelítette meg. 2019-ben 2018-hoz képest az államadósság 1,4 százalékkal 6,53 milliárd USD-ra csökkent. A GDP-arányos teljes államadósság 2020-ban várhatóan 40,3 százalékra nő, a Világbank 2020-ban a költségvetési hiány növekedését (3,7 százalék) prognosztizálja (WBG 2020b). A pandémia okozta gazdasági károk jelentősek, a Focus Economics 2020. november 3-i adatai alapján ${ }^{10} 2020$-ban a GDP reálnövekedés $-5,3$ százalék, míg 2021-re 3,9 százalék prognosztizálható.

A kereskedelmi mérleg hiánya is aggodalomra adhat okot: a Központi Bank adatai alapján a 2018-ban mért 4,9 milliárd KM hiány 25,8 százalékkal kisebb a 2014-es 6,2 milliárd KM értéknél. 2015-től a hiány folyamatosan, de egyre kisebb mértékben csökkent, ezzel szemben 2019-ben 5,2 milliárd KM-ra nőtt, és azóta ezen a szinten stabilizálódott.

2019-ig a folyó fizetési mérleg hiánya magas, mert a kereskedelmi mérleg hiányát a fizetési mérleg egyéb elemeinek többlete nem képes ellensúlyozni. 2019-ben az export 14,28 milliárd KM-t tett ki, amely alig 0,5 százalékkal több az előző évhez képest. Az import értéke további 1,5 százalékkal nőtt, és elérte a 19,4 milliárd KMt. A külkereskedelmi deficit 2020 első két negyedévében mérséklődött, mivel az import a közlekedési és szállítási szolgáltatások jelentős csökkenése miatt jobban csökkent, mint az export. A 2015-ös bázisévhez képest 2016-ban az exportárindex 2,6 százalékkal, az importárindex 4,3 százalékkal csökkent. 2017-ben az exportárindex 2,4 százalékkal, az importárindex 0,8 százalékkal, 2018-ban 6,9 százalékkal, illetve 4,1 százalékkal, 2019-ben 7 százalékkal, illetve 4,5 százalékkal, 2020. második negyedévében 3,8 százalékkal, illetve 2,7 százalékkal növekedett (AS of BiH 2020). Vjekoslav Vukovic, a Bosznia-Hercegovinai Külkereskedelmi Kamara igazgatójának nyilatkozata szerint „A kereskedelmi hiány növekedését elsősorban a koszovói piac elvesztése és a mostari alumíniumgyár csődje okozta"11. Felmerül a kérdés, hogyan tud ekkora kereskedelmi deficitet elviselni Bosznia-Hercegovina a folyó fizetési

\footnotetext{
${ }^{10}$ Bosnia Economic Outlook. FocusEcoomics, 2020. november 3. https://www.focus-economics.com/countries/ bosnia-and-herzegovina. Letöltés ideje: 2021. május 2.

${ }^{11}$ Schroeder, M.: Instrument for Pre-Accession Assistance (IPA) to Bosnia-Herzegovina. EU Delegation to Bosnia and Herzegovina, 2013. http://europa.ba/wp-content/uploads/2015/05/delegacijaEU_2013121012030960eng.pdf. Letöltés ideje: 2020. október 30.
} 
mérlegében, ellensúlyozhatják-e ezt együttesen a tőkebeáramlások, az uniós előcsatlakozási források, a nemzetközi donációk és a humanitárius segélyek?

Az UNOCHA adatbázisa tartalmazza, hogy a 2008-2009-es gazdasági világválság idején Bosznia-Hercegovina az elmúlt években jelentősen megcsappant nemzetközi támogatások után 13 millió USD összegben kapott támogatást. A főbb donorországok továbbra is Németország, Ausztria, Svájc és az Egyesült Arab Emírségek. 2014-ig ismét folyamatosan apadtak el az országba érkező segélyek. 2012-ben alig 2,4 millió USD-t regisztráltak. 2014-ben - a délkelet-európai árvizek súlyos károkat okoztak, és Észak-Bosznia nagyobb részét elöntötte az ár - 20 millió USD rekordösszegben érkeztek segélyek, az Európai Bizottságtól 3,3 millió USD, az USA-tól 2,7 millió USD. A segélyalapok az élelmiszerbiztonságot és az aknamentesítést célozták, mert az áradások a háborúból visszamaradt aknamezők elhelyezkedését megváltoztatták, ami súlyos veszélyt jelentett a helyi lakosságra. A természeti katasztrófa hatására 2014-ben a 2013-ban ígéretes 2,4 százalékpontos reálnövekedés 1,1 százalékra esett vissza. 2018-ig radikálisan csökkent az országba érkező támogatások összege. 2019ben 7,8 millió USD pénzügyi hozzájárulás jelent meg a devizamérlegben. A balkáni menekültválság kezeléséhez az Európai Bizottságtól 4,3 millió USD humanitárius támogatás érkezett a Nemzetközi Migrációsszervezet és az ENSZ Menekültügyi Szervezet szarajevói misszióihoz. A Covid-19-járvány elleni közdelemben Bosznia-Hercegovina 22 millió USD segélyt kapott az egészségügyi szektor megerősítéséhez, elsősorban az Európai Bizottságtól ( 5 millió USD) és az Egyesült Arab Emírségektől (8,6 millió USD).

A devizamérleg egyensúlyozásában az EU előcsatlakozási támogatási forrásai (IPA) ${ }^{12}$ is kardinális szerepet kapnak, ez 2011-ben és 2012-ben a legmagasabb, évi közel 108 millió euro volt, bár a folyó fizetési mérlegben pont e két évben volt a legnagyobb deficit, GDP-arányosan 2011-ben közel 10 százalék, 2012-ben közel 9 százalék. 2013-ban Brüsszel megvonta a Szarajevónak szánt éves 109 millió eurós támogatás felét, amiért nem tudtak megállapodni az Emberi Jogok Európai Bírósága által a Sejdić-Finci-ügyben ${ }^{13}$ hozott alkotmánymódosítási javaslat végrehajtásáról. Ezzel a 2014-2020-as uniós költségvetési időszakra az IPA-II-ből származó támogatási öszszegek is veszélybe kerültek. Az IPA-I-szerződések 39 százalékát bosznia-hercegovinai vállalkozókkal kötötték, és a politikai instabilitás miatt több, a vidékfejlesztést célzó előcsatlakozási támogatási eszközt (IPARD) megcélzó agrárfejlesztés becsődölt ${ }^{14}$.

Az uniós reformelvárások, a koordinációs mechanizmus, a politikai egységesség és szociális igazságosság hiányában az IMF is kénytelen volt 2014-ben felfüggeszteni a készenléti hitelmegállapodását. 2016 májusában született csak újabb

\footnotetext{
12 Instrument for Pre-Accession Assistance, IPA

${ }^{13}$ Lásd bővebben pl.: https://www.vajma.info/cikk/tukor/5297/Bosznia-a-Sejdic-Finci-ugy-arnyekaban.html. Letöltés ideje: 2021. április 28.

${ }^{14}$ Lásd a 8. lábjegyzetet.
} 
megállapodás, amely szerint az IMF az 550 millió eurót három évre folyósítja kamat nélkül - de szolgáltatási díjjal, amelyet attól függően számolnak, hogy az ország a kiosztott IMF-kvótából mekkora összeget vesz igénybe -, 13 éves futamidővel, beleértve a 4,5 éves türelmi időt ${ }^{15}$. Az IMF-tól 2016-ban Bosznia-Hercegovina 200 millió euro helyett csak 100 millió eurót kapott meg, míg a Világbank 50 millió USDos támogatása, amelyet már a 2016-os költségvetésben is beszámítottak, 2017-re csúszott ${ }^{16}$. Több mint egyéves politikai holtpont után, amikor is a 2018. októberi általános választásokat követően a boszniai politikusok 14 hónapig nem tudtak koalíciót alakítani, 2019 decemberében újabb tárgyalások indulhattak az IMF-fel, és a 2018-2020 közötti időszakban az IPA-II keretében elkülönített 314,9 millió euro indikatív összeg felhasználása (a 2014-2020-es költségvetési időszakra odaítélt 552,1 millió eurós össztámogatásból) is folytatódott. A Covid-19-járvány kezelésére és a gazdasági rehabilitációhoz 2020 áprilisában az IMF jóváhagyott egy 330 millió eurós sürgősségi kölcsönt, míg az Európai Bizottság további 250 millió eurót különített el Bosznia-Hercegovinának ${ }^{17}$. A 2019-2021-es stratégiájában a Bosznia-Hercegovinai Föderáció becslései szerint adósságkezelésre a hároméves költségvetési periódusra 1,06 milliárd dollárnak megfelelő külső finanszírozásra lesz szüksége, amelyet multilaterális pénzügyi intézményektől próbál hitelként felvenni, így az összes szükséges forrás 62,2 százalékát biztosítani tudják. A bosznia-hercegovinai Szerb Köztársaság 2019-2021-es adósságkezelési stratégiájának középpontjában a hosszabb lejáratú értékpapírok kibocsátása áll. Stratégiája a finanszírozási források, az eszközök és a befektetők diverzifikálása, de a külső finanszírozás arányának csökkennie kell a belső finanszírozás javára. ${ }^{18}$

A közvetlen tőkebefektetések mértéke kevesebb, mint a nettó pénzügyi hazautalások. Ennek legfőbb oka a háború okozta károk mellett a későn induló gazdasági fejlődés, a stagnáló belső fogyasztás, a költségvetés leterheltsége, a bürokrácia és jogrendszer szövevényessége, a pártpolitikai csatározások, az alacsony bérek, a magas munkanélküliség és a lassan haladó privatizáció. Amíg 2009-re a boszniai Szerb Köztársaságban a nagyobb állami tulajdonú vállalatok privatizációja lezárult, addig a Bosznia-Hercegovinai Föderációban a telekommunikációs, illetve az energiaszektorban a folyamat még tart. A Föderáció nagyobb FDI-beáramlásra számíthat (Peštek et al. 2021). A Bosznia-Hercegovinai Föderáció Szövetségi Privatizációs Ügynökségének 2020-as pénzügyi munkaterve alapján a tőke 43 százalékát privatizálták, 1088 vállalkozás privatizációja befejeződött, összesen 2604 vállalkozást értékesítet-

\footnotetext{
${ }^{15}$ Latal, S.: Bosnia Clinches New €550m Deal With IMF. BalkanInsight, 2016. május 20. https://balkaninsight. com/2016/05/25/bosnia-to-get-new-550-million-program-from-imf-05-25-2016/. Letöltés ideje: 2020. november 11 .

${ }^{16}$ uo.

${ }^{17}$ Dervisbegovic, N.: Budget Delays Force Bosnia to Postpone Local Elections. BalkanInsight, 2020. május 23. https://balkaninsight.com/2020/05/23/budget-delays-force-bosnia-to-postpone-local-elections/. Letöltés ideje: 2020. november 11.

${ }^{18}$ Outlook 2020 Bosnia \& Herzegovina. bnelntellinews.com, 2020. január 7. https://www.intellinews.com/ outlook-2020-bosnia-and-herzegovina-174066/. Letöltés ideje: 2020. november 11.
} 
tek a kisléptékű privatizáció feltételeivel. ${ }^{19} \mathrm{Az}$ EU-s piacok közelsége, a szakképzett munkaerő és az alacsony munkaerőköltségek motiválták a befektetéseket (Peštek et al. 2021). A privatizáció az ország három entitásában kiemelt lehetőség, de egyben kockázat is. Az IMF adatai alapján Santrucek rámutat ${ }^{20}$, hogy a jellemzően alacsonyabb termelékenységű állami tulajdonú vállalatok teljes adóssága a GDP körülbelül 26 százaléka, ami olyan strukturális problémákra vezethető vissza, mint a patronázsrendszer (klientelizmus), a korrupció (a közbeszerzések nem átláthatósága), az etnicizálódás. Susic és szerzőtársai (2017) szerint Bosznia-Hercegovina gazdasági fejlődését nem az akadályozza, hogy a gazdaság nem képes termelni, hanem hogy a tőke azoknak a kezébe kerül, akik azt nem produktívan használják fel ${ }^{21}$.

A közvetlen külföldi tőkebefektetéseket 2001-től regisztrálják. Az FDI beáramlását a gazdasági világválság jelentősen csökkentette, a nettó befektetések növekedését 2014-ben mutatták ki (414,7 millió euro), ami majdnem duplája a 2013-as adatoknak. 2015-ben és 2016-ban az FDI-beáramlás nem mutatott pozitív tendenciát. 2017-ben a korábbi, mérséklődést mutató FDI-trend megállt, a közvetlen külföldi befektetések 2017-ben 436,4 millió eurót tettek ki. 2018-ban az FDI 2017-hez képest 11,5 százalékkal nőtt, és a 487 millió euro a legmagasabb éves FDI 2009 óta. A közvetlen külföldi befektetések összege 2019-ben 357 millió euro, ami 26,6 százalékos csökkenést jelent. A FIPA (2020) közleménye szerint, a beruházások alacsonyabb beáramlását többek között a megnövekedett osztalékfizetés okozta 2019 utolsó negyedévében, valamint a külföldi tulajdonú társaságok helyi vállalatok általi felvásárlása.

Bosznia-Hercegovina ipari hagyományának köszönhetően az FDI legnagyobb részét a feldolgozóiparban (35 százalék) - ezen belül kiemelten a koksz és finomított kőolajtermékek és a vegyipari termékek gyártásában -, valamint a bankszektorban (25 százalék) jegyezték be, de 12 százalékkal az infokommunikációs szektor is említésre méltó. A tőkebefektetésekből kis összeget fordítottak exportorientált termelésre annak ellenére, hogy az fontos az ország versenyképességének növelése szempontjából (Čaušević 2015). 2020 első félében a közvetlen külföldi tőkebefektetések 46,7 százalékkal csökkentek az előző év azonos időszakához képest. A Covid-19-járvány következtében az FDI világszerte várhatóan 30-40 százalékkal csökken, ami súlyos nyomást jelent Bosznia-Hercegovinában is.

${ }^{19}$ Federation of Bosnia-Herzegovina Entity privatized 1,088 Enterprises. Sarajevo Times, 2020. február 21. https://www.sarajevotimes.com/federation-of-bosnia-herzegovina-entity-privatized-1088-enterprises/. Letöltés ideje: 2020. október 30.

20 Santrucek, S.: Failed Privatisation is to Blame for Bosnians' Exodus. BalkanInsight, 1999. május 16. https:// balkaninsight.com/2019/05/16/failed-privatization-is-to-blame-for-bosnians-exodus/. Letöltés ideje: 2020. november 11.

${ }^{21}$ Santrucek példának hozza fel a privatizációs folyamat etnizálásának veszélyeire a Hercegovina-Neretva kanton legnagyobb állami vállalatának, az Aluminij Mostarnak a bezárása 2020 júliusában. Az egykor legnagyobb alumíniumexportőr társaság privatizációja 2010-ben hivatalosan is megbukott. A korábban győztesnek hirdetett konzorcium, a Glencore-Feal és a Dalekovod Zagreb kizárólag a HDZ BiH (BoszniaHercegovinai Horvát Demokratikus Közösség) párthoz kapcsoló horvát befektető volt. (A forrást lásd a 17. lábjegyzetnél.) 
A CBBH (2020) adatai szerint az országba 1994-től 2019 végéig beáramló mintegy 7,7 milliárd euro külfölditőke-állomány legfontosabb származási országai: Ausztria (1,4 milliárd euro), Horvátország (1,2 milliárd euro), Szerbia (1,0 milliárd euro) és Szlovénia (554 millió euro). 2019-ben jelentős tőkebefektetés érkezett az Egyesült Királyságból (43,5 millió euro), Luxemburgból (14,3 millió euro), Szaúd-Arábiából (11,2 millió euro) is. 2020-ban a legtöbb beruházás az EU27-ből érkezett. A CEFTA-tagok közül Szerbia a legfontosabb gazdasági partner, elsősorban a boszniai Szerb Köztársaság számára. A 2018. évi országos összesített közvetlen külföldi tőkebefektetések 40 százaléka is ide irányult (szemben a 2016-os 13 százalékkal). Az orosz tőke továbbra is nagy szerepet játszik az entitáson belüli privatizációban ${ }^{22}$. A legnagyobb orosz beruházások az olajfinomítók tőkésítése Modricában, Bosanski Brodban és Banja Lukaban (Čaušević 2015). A vállalatok az Optima Csoport részét képezik, amelynek többségi tulajdonosa a NefteGazlnkor, az orosz Zarubezhneft leányvállalata.

Míg az orosz befektetők jelentős szerepet játszanak a boszniai Szerb Köztársaságban, a többségben bosnyákok lakta Bosznia-Hercegovinai Föderáció vonzza a törököket és az Öböl-menti arab országokat. A maglaji papír- és cellulózgyár, a Natron 2005-ös privatizációja az eddigi legnagyobb török beruházás. Az SDA (Demokratikus Akciópárt) támogatásával és erősödő bankszektori jelenlétével Törökország pozíciói konszolidálódtak. ${ }^{23}$ A Föderáció ingatlanpiacán egyre aktívabbak a befektetők Dubaiból, Katarból, Kuvaitból és Szaúd-Arábiából. ${ }^{24}$. A relatív többségben bosnyákok lakta közép-nyugat hercegovinai részen is megjelentek az arab befektetőket képviselő ingatlanügynökségek. Richet (2019) tanulmánya rámutat az erősödő kínai tőkére az infrastrukturális és energiaprojektekben. A Stanari 300 MW-os hőerőmúvet a Kínai Fejlesztési Bank finanszírozza. Az erősödő orosz, török, arab és kínai befektetések gyengíthetik az Európai Unió jelenlétét. Az iszlám világ gazdaságainak egyre látványosabb lenyomata az EU-s integrációs perspektívákat gyengíti, ami a török példán is nyomon követhető. Az erős vallási mérce ellentmond az $\mathrm{EUSz}^{25} 2$. cikkében rögzített pluralizmus és tolerancia értékeinek. Bosznia-Hercegovina nemzeti integritásának szempontjából az arab muzulmán jelenlét nemcsak a boszniai szerbeknél és a boszniai horvátoknál okoz társadalmi, gazdasági és biztonságpolitikai feszültséget, hanem a sajátos európai tradícióval, liberálisabb szemlélettel rendelkező bosnyákok esetében is.

\footnotetext{
22 Đorđević, N.: FDI in Bosnia's Republika Srpska is increasing, but there's plenty of room for more. Emerging Europe, 2020. július 16. https://emerging-europe.com/news/fdi-in-bosnias-republika-srpska-is-increasingbut-theres-plenty-of-room-for-more/. Letöltés ideje: 2020. november 11.

${ }^{23}$ Forrás: Santrucek, lásd a 17. lábjegyzetnél.

${ }^{24}$ A szarajevói „Bristol” szálloda, az 50 millió eurós „BBI” bevásárlóközpont, az ilidzsai lakópark-komplexum, a „Poljine Hills” arab beruházásként valósultak meg. Ilidzában egy szaúdi holding 2 milliárd euróból DélKelet-Európa legnagyobb idegenforgalmi beruházását, a Buroj-Ozone-t építi. (Brunwasser, M.: Bosnia's biggest foreign investment: Bonanza or threat? BBC News, 2016. szeptember 22.) https://www.bbc.com/ news/business-37429682. Letöltés ideje: 2020. november 11.

${ }^{25}$ https://eur-lex.europa.eu/resource.html?uri=cellar:2bf140bf-a3f8-4ab2-b506-fd71826e6da6.0007.02/ DOC_1\&format=PDF
} 
A folyó fizetési mérleg negatív egyenlegét csökkentő jelentős tétel a hazautalások összege. A CBBH (2020) adatai alapján 2019-ben Bosznia-Hercegovinába 2,3 milliárd USD érkezett hazautalásként, amely összeg az éves GDP-jének körülbelül 11 százaléka. Bár még ez sem ellensúlyozza a kereskedelmi hiányt, de csökkenti. A TheGlobalEconomy.com 2019-es adatai alapján ${ }^{26}$ Bosznia-Hercegovina a GDPhez viszonyított hazautalások mértékében világviszonylatban a huszadik helyen áll, Európában pedig Moldávia után (16 százalék) a második. A hazautalásainak növekedési rátája 2000 és 2008 között az egyik legdinamikusabb (2008-ban 2,7 milliárd USD befizetés érkezett), és az első generációs kivándorlók hazautalásait tükrözi. A boszniai-hercegovinai Emberi Jogi és Menekültügyi Minisztérium jelentései szerint jelenleg legalább 2 millió bosznia-hercegovinai ember él külföldön, ami az ország lakosságának az 56 százaléka. Az átutalások felhasználásáról kevés elemzés áll rendelkezésünkre, de a szórványos bizonyítékok arra utalnak, hogy az átutalásokat elsősorban az alapfogyasztásra, a háztartások kiadásaira fordítják, így azok csekély hatást jelentenek a befektetésekre (Oruč 2011; Jakobsen - Strabac 2015). A Nemzetközi Migrációs Szervezet 2007-es adatai és előrejelzései alapján közép- és hosszú távon a hazautalások növekedése visszaesik, mihelyt a másodés harmadgenerációs kivándorlók csökkentik, illetve abbahagyják hazautalásaikat.

Összeségében elmondható, hogy a pénzátutalások nemcsak Bosznia-Hercegovina esetében, hanem a fejlődő országokra nézve általában a legnagyobb külső finanszírozási forrássá váltak. 2018-ban globális szinten a fejlődő országoknak történő átutalások (462 milliárd dollár) már lényegesen nagyobbak voltak, mint a közvetlen külföldi befektetések (344 milliárd dollár) (WBG 2019). Tehát az olyan perifériális nemzetgazdaságok esetében, mint Bosznia-Hercegovina is - ahol az átutalások dinamizmusa a GDP százalékarányos összetételében 9 százalékkal nagyobb, mint a közvetlen tőkebefektetéseké - az átutalások váltak a legnagyobb devizabevételi forrássá.

A jellemzően agráripari jellegű ország revitalizációja megindult, de teljes állapotát a mai napig nehéz felmérni, mert az egész államra, illetve entitásokra vonatkozó statisztikai adatokat több faktor is befolyásolja. Egyrészt a hivatalos statisztika nem mindig számol az országszerte elterjedt és minden társadalmi rétegben jelentős mértékű szürkegazdasággal és feketegazdasággal. A bosznia-hercegovinai Statisztikai Hivatal adatai szerint, habár a hivatalos munkanélküliség 2013-2014-ben 40 százalék körüli volt, 2017-ban 21 százalék és a legutóbbi 2019-es adatok szerint 16 százalék. Ezen belül azonban kiugró adat a fiatalok (15-24 évesek) 48 százalékos munkanélkülisége. A szürke- és feketegazdaság sokak megélhetését biztosítja, így a tényleges munkanélküliség körülbelül 10 százalékponttal alacsonyabb lehet. A Covid-19-járvány főleg a szolgáltató szektorban okozhat 2020-2021-ben növekvő

${ }^{26}$ Remittances, percent of GDP in Europe. The Global Economy, 2019. december 31. https://www.theglobaleconomy.com/rankings/remittances_percent_GDP/Europe/. Letöltés ideje: 2021. május 2. 
leépítéseket. Az Eurostat (2019) adatai megerősítik, hogy a szociális hálót és az önfenntartást további veszélyeztető tényező a nyugat-balkáni viszonylatban kiugróan magas elvándorlás (2015-2020 között -6,4 százalék nettó migrációs arány), az alacsony 1,3-es reprodukciós ráta és a felgyorsuló társadalmi elöregedés (43 év az átlagéletkor). A szomszédos Szerbiával, Észak-Macedóniával és Koszovóval összehasonlítva az elnéptelenedés elérte a húszéves csúcsot. 1991-től számítva 2050-re a népesség közel 29 százalékkal csökkenhet, a 2060-ra prognosztizált átlagéletkor 53 év (UN DESA 2019). Mind a termelői, mind a tudásalapú szolgáltatásszektornak komoly kihívás, hogy Bosznia-Hercegovina a világ országai között - Haiti és Venezuela után - harmadik az agyelszívás vesztesei között (WEF 2018). A nyugdíjalapok nem jelentősek, hiányzik a 3 pilléren nyugvó nyugdíjrendszer. A biztosítási szektor szintén nem játszik szerepet a pénzügyi intermediációban, habár folyamatban van a biztosítási törvény elfogadása, jelenleg is a nem-életbiztosítások dominálják a biztosítók portfólióit. Gazdasági téren az entitások egymástól eltérő gazdasági elképzelései, egyenetlen gazdasági fejlődésük is gondot okoz. A központi kormányzat mellett a kantonális és önkormányzati szinteken is megmaradtak olyan hatáskörök, amelyek nehezítik az állami garanciavállalást és a hitelfelvételt. Habár a nemteljesítő hitelek aránya folyamatosan csökken (2019-ben 9 százalék alatt volt), a válság előtti 3 százalékos szintnek csaknem a háromszorosa, ami a hitelezési aktivitást és a bankszektor jövedelmezőségét is terheli ${ }^{27}$.

\section{7. Összefoglalás és következtetések}

Az esszé Bosznia-Hercegovina 2000-2020 közötti külgazdasági lehetőségeit elemzi, érintve a magyar relációt. A jelenlegi európai uniós külpolitikai és külgazdaság-fejlesztési programokban is szerepel az EU-tagságra pályázó országok kapcsolatainak átfogó értékelése. Nyugat-Balkán makrogazdasági fejlesztését jelenleg a 2020 utáni kohéziós politika és a Covid-19-járvány gazdasági kihívásai között kell megvitatni.

Nem lehet eltekinteni a balkáni háborútól, az elveszett évtizednek is nevezett 1990es évektől. A GDP 1991-től 1992-re 80 százalékkal, 1991-ről 1995-re kétharmaddal visszaesett, a 4,3 millió fős népesség 1995-re az atrocitások és a menekültáradat eredményeként 1 millió fővel csökkent. A daytoni rendszer államigazgatása nagyon drága, és csak lassan bontakoznak ki a piacgazdaság, a tőkeáramlás, a privatizáció és az európai felzárkózás alapjai. Huszonöt évvel a háború befejezése után Bosznia-Hercegovina a politikai és kormányzati irányítás széthúzásával küzd. Az etnicizálódás, a klientelizmus, a feketegazdaság, a nemzetközi közösség balkanizmusa és eltérő belpolitikai érdekeltségei Bosznia-Hercegovinában a fenntartható gazdasági fejlődés gátjai.

\footnotetext{
${ }^{27}$ Forrás: Outlook 2020 Bosnia \& Herzegovina, lásd a 15-ik lábjegyzetnél.
} 
A gazdasági újjáépítéshez és megbékéléshez nyújtott 5 milliárd USD nemzetközi segélyt követően a gazdaság növekedésnek indult. 1998-ban kibocsátották az új nemzeti pénzt, a konvertibilis márkát, amely egységesítette a három entitás pénzügyi szféráját. A konvertibilis márka bevezetésével megszűnt a három államalkotó nemzet eltérő monetáris rendszere. A konvertibilis márka árfolyamát a német fizetőeszközhöz kötötték. Miután a német márkát felváltotta az euro, a konvertibilis márkát ugyanazon az árfolyamon váltották be az EU új fizetőeszközére, mint a német márkát. A currency board eredményeként az inflációt sikerült leszorítani és alacsonyan tartani, illetve visszanyerni a befektetők és a lakosság nemzeti fizetőeszköz iránti bizalmát.

A 2008 közepén életbe lépett ideiglenes, majd a 2015-től múködő Stabilitási és Társulási Megállapodás alapján a szabadkereskedelmi rendszer elősegíti Bosznia-Hercegovina külgazdasági lehetőségeinek fejlődését. E kis, nyitott gazdaság lehetőségeit növeli az EU közelsége, a jól képzett munkaerő, az exportlehetőség a fafeldolgozás, a fémipar, az autóipar, az energiaszektor, a nemzetközi szállítmányozás és az idegenforgalom ágazataiban. A nagyüzemi termelés a mezőgazdaság exportlehetőségeit is javítja. Bosznia-Hercegovina és Magyarország gazdasági kapcsolatában az áruforgalom dominál, a magyar behozatali volumen 90 százalékát a feldolgozott termékek teszik ki. A szolgáltatások külkereskedelmi értéke 2008-tól 2019 végéig megduplázódott. Gazdasági kapcsolatunk 2018-ig élénkült, majd egyre negatívabb a változás, a magyar aktívum jelentős.

A háború utáni évtizedben nőtt az importfüggőség, ami hitelfelvételekhez vezetett. A lassuló privatizáció nehezíti az áttérést egy exportorientált gazdaságra. A privatizációs folyamatok fejlesztése, a magánszektor intenzívebb bevonása a nemzetközi versenyképesség kulcspontjai. A privatizáció és az FDI beáramlása különböző periódusokban indult meg az ország egyes entitásaiban. 2008-ig a Bosznia-Hercegovinai Föderáció nagyobb FDI-beáramlást regisztrált, mint a boszniai Szerb Köztársaság, 2009 óta a tendencia viszont fordított. 2020-ban a legtöbb beruházás az EU27-ből érkezett. Jelentősek a szomszédos országok beruházásai, Horvátország elsősorban a Föderáció, míg Szerbia a boszniai Szerb Köztársaság számára a legfontosabb gazdasági partner. Az orosz befektetés a boszniai Szerb Köztársaságban fontos, a többségben bosnyákok lakta Föderáció pedig a török és az Öböl-menti arab országokat vonzza. Bosznia-Hercegovinában erősödik a kínai FDI-beáramlás, indokolt arra számítani, hogy a nyugat-balkáni régiót polarizáló tőkebefektetések hatással lesznek az ország és az EU politikai, gazdasági dinamikájára. A közvetlen külföldi tőkebefektetések 2020 utáni növekedését a Covid-19-járvány okozta globális recesszió is mérsékelheti.

Bosznia-Hercegovina külgazdasági mozgását a belső gazdasági tér széttartása, a szerb-horvát-bosnyák nemzeti törésvonal is gyengíti. Az országon belüli divergencia lecsapódik a gazdaság teljesítőképességén és a szociális jólétén, amelynek növeke- 
dési lehetőségét a tömeges elvándorlás és a társadalom elöregedése is fenyegeti. A gazdasági kivándoroltak átutalásai fontos jövedelemforrást jelentenek az ország lakossága számára. A pénzátutalás hatszor nagyobb, mint az FDI, és háromszor meghaladja a fejlesztési támogatás GDP alapú százalékát is. A pénzátutalások rövid távon hasznos és nélkülözhetetlen szerepet töltöttek be az intézményi szociális támogatások kiegészítésében, az alacsony közvetlen külföldi befektetések negatív hatásainak a tompításában. Az állampolgárok folyamatos emigrációja segíti fenntartani a pénzátutalások jelenlegi magas szintjét, így az elvándorlás ebből a szempontból nem feltétlenül negatív, de ez csak az ország rövid távú kilátásai szempontjából igaz. A hazautalások azonban hosszabb távon növelik Bosznia-Hercegovina függőségét, fokozzák a gazdaság sérülékenységét, amennyiben az átutalások mértéke a generációs változással elapad. Emellett beáramlásuk lassíthatja a szükséges gazdasági reformokat, mivel a beruházások helyett a fogyasztást ösztönzik, és így csökkentik a hazai gazdaság versenyképességét és a munkaerő aktivitását mindaddig, amíg a háztartásokban az otthoni munkaerő révén megszerzett jövedelem helyettesítője. A hazautalások kiegyensúlyozzák a devizamérleget, azonban a cél csak az lehet, hogy az ország a nemzetközi pénzügyi hozzájárulásoktól való függőségtől a megnövekedett exporttevékenységre épülve a kiegyensúlyozott kereskedelmi mérleg irányába mozduljon el.

Mind a Balkán, mind Európa érdeke Bosznia-Hercegovina politikai és gazdasági stabilitásának az elérése és fenntartása. Ehhez elengedhetetlen feltétel az Európai Unió politikai támogatása és gazdasági segítsége.

\section{Felhasznált irodalom}

AS of $\mathrm{BiH}$ (2020): Unit value indices of export and import of BiH. Agency for Statistics of Bosnia and Herzegovina, Q3 2020. Sarajevo. http://www.bhas.ba/data/Publikacije/ Saopstenja/2020/ETR_02_2020_Q3_0_HR.pdf. Letöltés ideje: 2020. november 28.

AS of $\mathrm{BiH}$ (2021): BiH International Trade in Goods Statistics, January 2021. Agency for Statistics of Bosnia and Herzegovina, Sarajevo. http://www.bhas.ba/data/Publikacije/ Saopstenja/2021/ETR_01_2021_01_0_HR.pdf. Letöltés ideje: 2021. május 2.

Bakota, I. (2019): Bosnia-Herzegovina economy briefing: Industry in BIH and contribution to growth, exports and employment - overview. Kína-KKE Intézet, 19(2): 1-5.

Čaušević, F. (2013): Bosanska Ekonomska Enigma. O Tranziciji od 1996. do 2013. godine. Forum Bosnae, 63-64 (13). Međunarodni Forum, Sarajevo.

Čaušević, F. (2015): The political economy of economic liberalisation and competitiveness in Bosnia and Herzegovina. In: Thomas, M. - Bojicic-Dzelilovic, V. (eds.): Public policy making in the Western Balkans. Springer, Dordrecht, pp. 91-111. 
CBBH (2017): 20 Years of Stability 1997-2017. Central Bank of Bosnia and Herzegovina, Sarajevo. https://www.cbbh.ba/Home/GetTableAttachment?contentld=7b05d55d-ab21454b-b63a-ebd597adb6ef\&lang=en. Letöltés ideje: 2021. május 2.

CBBH (2020): Monthly Economic Survey, November 2020. Central Bank of Bosnia and Herzegovina, Sarajevo. https://www.cbbh.ba/content/DownloadAttachment/?id=fe8e2dc0-ec f9-4986-ad79-786506db538b\&langTag=en. Letöltés ideje: 2021. május 2.

ECHR (2009): Grand Chamber judgment: Sejdic and Finci v. Bosnia and Herzegovina. European Court of Human Rights, Strasbourg. https://hudoc.echr.coe.int/eng-press\#\{\%2 2itemid\%22:[\%22003-2974573-3281658\%22]\}. Letöltés ideje: 2020. november 11.

EC (2019): European Commission: Neighbourhood Policy and Enlargement Negotiations. https://ec.europa.eu/neighbourhood-enlargement/countries/detailed-countryinformation/bosnia-herzegovina_en. Letöltés ideje: 2020. november 11.

Estrin, S. - Uvalic, M. (2014): FDI into transition economies: Are the Balkans different? Economics of Transition, 22(2): 281-312. https://doi.org/10.1111/ecot.12040

Eurostat (2020): Western Balkans-EU - international trade in goods statistics. European Commission, Luxembourg. https://ec.europa.eu/eurostat/statistics-explained/index. php?title=Western_Balkans-EU_-_international_trade_in_goods_statistics\&oldid $=480316$. Letöltés ideje: 2020. november 7.

FIPA (2020): Bosnia and Herzegovina Investment Opportunities. Foreign Investment Promotion Agency of Bosnia and Herzegovina, Sarajevo. http://www.fipa.gov.ba/ publikacije_materijali/brosure/INVESTMENT\%20OPPORTUNITIES\%2028.07.2020.pdf. Letöltés ideje: 2021. május 2.

Goldstein, E. - Davies, S. - Fengler, W. (2015): Three reasons why the economy of Bosnia and Herzegovina is off balance. Brookings.edu, november 5. https://www.brookings.edu/ blog/future-development/2015/11/05/three-reasons-why-the-economy-of-bosnia-andherzegovina-is-off-balance/. Letöltés ideje: 2020. november 22.

Huszka, B. (2015): Hungary. In: Balfour, R. - Stratulat, C. (eds.): EU member states and enlargement towards the Balkans. European Policy Centre, Brussels, pp. 115-128.

Ilgün, E. - Coskun, A. (2009): Foreign Direct Investments in Bosnia and Herzegovina: Banking Sector Example. Alatoo Academic Studies, 4(2): 49-67.

Jakobsen, J. - Strabac, Z. (2015): Remittances, Institutions and Development in BosniaHerzegovina. In: Kostic, R. - Cosic, E. - Babic, B. (eds.): Migration in the Function of Development. Ministry of Human Rights and Refugees of Bosnia-Herzegovina, Sarajevo, pp. 11-21. 
Karamehic-Muratović, A. - Kromják, L. (2021): Remembrance and Forgiveness: Global and Interdisciplinary Perspectives on Genocide and Mass Violence. Routledge, London and New York.

Kovać, O. (1995): Foreign Economic Relations. In: Adamovich, L.S. - Ramet, S.P. (eds.): Beyond Yugoslavia: Politics, Economics, and Culture in a Shattered Community, Westview Press, pp. 281-300. https://doi.org/10.4324/9780429044670

KSH (2020): A külkereskedelmi termékforgalom forintban, országok szerint (2001-2019). Központi Statisztikai Hivatal, Budapest. http://www.ksh.hu/docs/hun/xstadat/xstadat_ eves/i_qkt009a.html. Letöltés ideje: 2020. november 11.

Lloyds Bank (2019): Foreign trade figures of Bosnia and Herzegovina, Bosnia and Herzegovina: Economic and Political Overview. https://www.lloydsbanktrade.com/en/market-potential/ bosnia-and-herzegovina/trade-profile. Letöltés ideje: 2020. november 11.

MKIK (2020): Piaci útmutató Bosznia-Hercegovináról. Magyar Kereskedelmi és Iparkamara, Budapest. https://mkik.hu/download/207/bosznia-hercegovina. Letöltés ideje: 2021. május 2.

Oruč, N. (2011): Do Social Transfers "Crowd-Out" Remittances: Evidence from Bosnia. The wiiw Balkan Observatory: Working Papers 92. https://wiiw.ac.at/do-social-transfers-crowdout-remittances-evidence-from-bosnia-dlp-3201.pdf. Letöltés ideje: 2020. november 7.

Pap Norbert (2004): Bosznia-Hercegovina külgazdasága. In: M. Császár Zsuzsa (szerk.): Bosznia-Hercegovina a harmadik Balkán-háború után. Balkán füzetek, 2004(2): 51-58. http://epa.oszk.hu/02100/02108/00002/pdf/EPA02108_Balkan_Fuzetek_2004.pdf. Letöltés ideje: 2020. november 11.

Peštek, A. - Lazović-Pita, L. - Abdić, A. (2021): FDI in Bosnia \& Herzegovina. In: Deichmann, J.I. (ed.): Foreign Direct Investment in the Successor States of Yugoslavia: A Comparative Economic Geography 25 Years Later. Springer, Dordrecht, pp. 109-166.

Pugh, M. (2002): Postwar political economy in Bosnia and Herzegovina: The spoils of peace. Global Governance, 8(4): 467-482. https://doi.org/10.1163/19426720-00804006

Pugh, M. (2005): Transformation in the political economy of Bosnia since Dayton. International Peacekeeping, 12(3): 448-462. https://doi.org/10.1080/13533310500074564

Richet, X. (2019): Geographical and Strategic Factors in Chinese Foreign Direct Investment in Europe. Asian Econ Papers, 18(2): 102-119. https://doi.org/10.1162/asep_a_00700

Sells, M. (1996): The Bridge Betrayed: Religion and Genocide in Bosnia. University of California Press, London. 
Susic, I. - Stojanovic-Trivanovic, M. - Susic, M. (2017): Foreign direct investments and their impact on the economic development of Bosnia and Herzegovina. IOP Conference Series Materials Science and Engineering 200(1): 1-16. https://doi.org/10.1088/1757$899 X / 200 / 1 / 012019$

Tzifakis, N. - Tsardanidis, C. (2006): Economic reconstruction of Bosnia and Herzegovina: The lost decade. Ethnopolitics, 5(1): 67-84. https://doi.org/10.1080/17449050600576316

UN DESA (2019): UN Department of Economic and Social Affairs: World Population Prospects 2019. United Nations, New York. https://population.un.org/wpp/Publications/Files/ WPP2019_Volume-I_Comprehensive-Tables.pdf. Letöltés ideje: 2020. október 30.

Varga Imre (2009): Magyarország és Bosznia-Hercegovina kapcsolatai. Balkán füzetek, 2009(2): 217-221. http://epa.oszk.hu/02100/02108/00011/pdf/EPA02108_Balkan_ Fuzetek_2009_2_217-221.pdf

Vučetić, S. (2002): Peacebuilding and political corruption: the Bosnia case. South-East Europe Review, 5(3): 65-80.

WBG (2017): The Stabilization and Association Agreement (SAA) between Bosnia and Herzegovina (BiH) and the European Union: Impacts of the Adaptation Protocol (AP) on the Agriculture and Food Sector. World Bank Group, Washington, DC. https://openknowledge. worldbank.org/handle/10986/28222?show=full. Letöltés ideje: 2020. november 7.

WBG (2019): Western Balkans Regular Economic Report No. 15, Spring 2019: Reform Momentum Needed. World Bank Group, Washington, DC. https://openknowledge. worldbank.org/handle/10986/31506. Letöltés ideje: 2020. november 7.

WBG (2020a): Western Balkans Regular Economic Report No.18, Fall 2020: An Uncertain Recovery. World Bank Group, Washington, DC. https://openknowledge.worldbank.org/ bitstream/handle/10986/34644/153774.pdf. Letöltés ideje: 2020. november 7.

WBG (2020b): Bosnia and Herzegovina: Outlook. World Bank Group, Washington, DC. http:// pubdocs.worldbank.org/en/130501492011101536/mpo-bih.pdf. Letöltés ideje: 2020. november 28.

WEF (2018): World Economic Forum: The Global Competitiveness Report. Geneva, Switzerland. http://www3.weforum.org/docs/GCR2018/05FullReport/TheGlobalCompetitivenessReport2018.pdf. Letöltés ideje: 2020. november 7. 